\title{
Flood risk management: cases studies in French Mediterranean area
}

\author{
Stéphanie Defossez ${ }^{1, a}$, Tony Rey ${ }^{1}$, Freddy Vinet ${ }^{1}$ and Laurent Boissier ${ }^{1}$ \\ ${ }^{1}$ UMR Gouvernance, Risques, Environnement, Développement (UPVM/IRD), 2196, bd de la Lironde, bât 4, 34980 Montferrier sur Lez. \\ France.
}

\begin{abstract}
For a long time, flood risk management in France was oriented around controlling the hazard with the installation of structural measures such as dikes. Since the 1990s, however, numerous events have shown that these measures are not always effective. As a result, institutions now consider that other actions, such as preventive measures, are possible. Risk management is based on public policies and involves a number of players, as well as the societies exposed to the risks. The goal of our study is to show the various orientations of risk management by looking at several examples from Mediterranean France, where flash floods are common, in particular using postevent analysis. Post-event observations let us evaluate the effectiveness of flood-management methods. Do public policies work, and do they have a real influence on reducing deaths and damage? Are individual measures overtaking collective ones? The main results of our study show that the event itself is more important in determining which measures are applied than public policies, which do not take into account local specificities.
\end{abstract}

\section{Introduction}

Over the last twenty years, the management of natural risks in France has evolved. Prevention and forecasting are slowly replacing a technical approach focused on protection at all costs. Despite a stated desire for a global, concerted management effort, in practice this effort runs into obstacles in the local context and/or in terms of acceptance by all the parties involved. The research presented here relates mainly to prevention, which appears to provide a solution for filling in the gaps left by structural measures. Prevention is seen as a complementary approach that involves all parties and combines collective and individual measures. In particular, Risk Prevention Plans (PPR in French), the flagship measure of prevention, will be studied in terms of both regulation of land use and mitigation of vulnerability. In addition, informing the public on the risks they face and preparing for crisis management also play a part in preventive management. Regulations and institutional management methods are not necessarily applied spontaneously. In general, the natural event serves as a trigger for the re-evaluation of measures and the implementation thereof.

\section{Evaluation of the effectiveness of preventive management}

Over the last two decades, risk management has been evolving. In this context, we think it is important to evaluate the effectiveness and the relevance of the measures taken. Instead of relying solely on structural measures, risk management now includes preventive measures and preparation for crisis management. Preventive measures include laws that regulate land use, but also measures that reduce vulnerability through one main tool, the Risk Prevention Plan. Prevention also involves informing populations and reminding them of the risks they face, making sure that they are aware of the risks and ready to face flooding.

The goal of evaluating these management measures is to identify strong and weak points and propose adaptation strategies. Adapting to risk helps reduce damage and, most importantly, lower the number of victims.

The evaluation of measures is based on a comparison of the goals set and the goals achieved [1, 2, 3].

Multiple surveys were carried out on various areas subject to flooding. The main results presented here come from surveys carried out in Cuxac-d'Aude and Coursan, in the Aude department (Fig.1). 


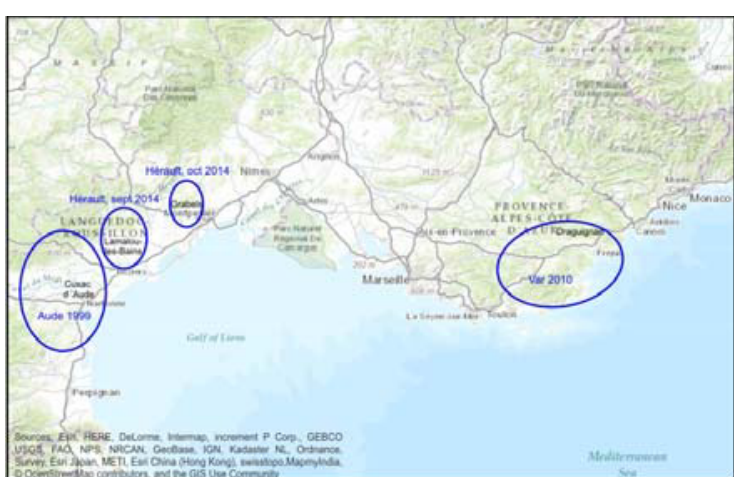

Figure 1. Location of study sites

In November 1999, flooding in the Aude, PyrénéesOrientales, Tarn and Hérault departments caused serious physical damage and multiple deaths. Five people perished in Cuxac-d'Aude, while in Coursan, the flooding caused little damage, even though both towns are in flood-prone areas. We have been monitoring risk management in this area for a number of years, allowing us to carry out surveys at ten-year intervals (2004 and 2015) in order to evaluate the effectiveness of the methods used, in particular the PPR. Another survey was carried out in Grabels after the floods of October 2014.

In addition to these surveys, we carried out postevent analyses after remarkable events, in particular in the Mediterranean area [3, 5, 6] (Table 1).

\begin{tabular}{|c|c|}
\hline Date of flood & Location \\
\hline November 1999 & $\begin{array}{c}\text { Hérault, Aude, Pyrénées- } \\
\text { Orientales and Lozère } \\
\text { departments }\end{array}$ \\
\hline June 2010 & Var department \\
\hline September 2014 & $\begin{array}{c}\text { Lamalou-les-Bains } \\
\text { (Hérault department) }\end{array}$ \\
\hline October 2014 & Grabels \\
(Hérault department)
\end{tabular}

Table 1. Post-event analysis of floods in the Mediterranean area Except for the events of 1999, for which the postevent analysis was carried out several years later, the post-event analyses involved going to the sites the day after and recording traces of the event. We were able to estimate the damage, the extent of the flooding and the water levels, and then we compared the flood-risk management measures in order to evaluate their effectiveness and relevance through field observations and formal and informal interviews.

By carrying out post-event analyses at various dates, we can show the evolution in risk management, in particular the implementation of preventive measures. For example, the Community Protection Plan ("Plan Communal de Sauvegarde" or "CPS" in French) instituted in 2004 and the Buyer-Renter Notice ("Information Acquéreur-Locataire" or "IAL" in French) instituted in 2006 constitute two mandatory measures. Even if these measures are fairly recent, we can already identify their strong and weak points.
Our methodology also involves assessing physical and human vulnerabilities using assessment criteria (Table 2) developed in other studies [7, 8].

\begin{tabular}{|c|c|c|}
\hline & Criteria & Indicators \\
\hline $\begin{array}{c}\text { Physical } \\
\text { vulnerability }\end{array}$ & $\begin{array}{c}\text { building type and } \\
\text { state }\end{array}$ & $\begin{array}{c}\text {-state of walls } \\
\text {-materials }\end{array}$ \\
\hline $\begin{array}{c}\text { Human } \\
\text { vulnerability }\end{array}$ & age, health & $\begin{array}{c}-80+\text { years old } \\
\text {-disabled }\end{array}$ \\
\hline
\end{tabular}

Table 2. Some examples of vulnerability criteria and indicators

The goal of this assessment is to estimate the potential damage and link it to the effectiveness of preventive measures, including mitigation. This will also allow us to propose adaptation strategies for reducing these vulnerabilities.

Our results relate to several areas in Mediterranean France that regularly undergo flash floods. These floods cause serious damage and deaths, such as in 1999 (35 deaths), 2002 (24 deaths) and 2010 (26 deaths). These events, characterized by high water levels and flow rates over a very short period of time, are brutal.

Although they are small towns, the areas studied are mainly urban areas that, for the most part, underwent rapid urban development in the 1960s. This development took place in the flood plains of rivers, and flooding has caused significant damage and deaths. The urban zone of the town of Grabels, for example, was extended into flood-prone areas (Fig. 2).

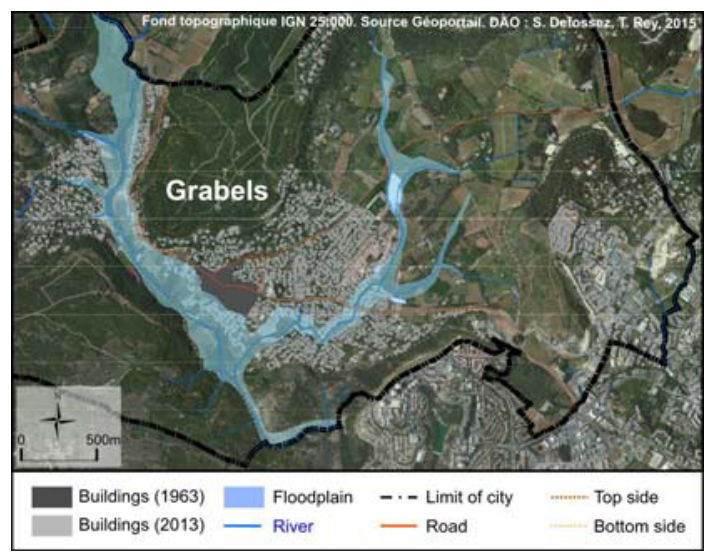

Figure 2. Urban development in Grabels 1960 to today, partly in a flood-prone area

\section{Preventive measures are recent and difficult to apply locally}

\subsection{The Risk Prevention Plan: a constraint?}

\subsubsection{A tool that came too late}

The main goal of this flagship management tool is to regulate land use, but it also proposes mitigation measures. Here, the evaluation of this tool will focus on 
land occupation. In all the cases studied, construction slowed, without completely stopping local development. New opportunities for building in free zones outside of flood-prone areas are appearing. But construction also took place in blue or even red zones (in Pérols in the Hérault department, new buildings were erected in the red zone subject to lagoon flooding). In blue zones, construction is authorized under certain conditions (e.g. floor above the highest recorded water levels), which can be considered adaptation to risk, but this type of recommended measure is never subject to inspection. This means that although these measures for reducing vulnerability are recommended, it is difficult to know whether they are applied. In the Aude department, interviews with local figures showed that the absence of inspections discourages the local population from respecting these recommendations in the long term. Moreover, institutions are rather opposed to inspections, and the Ministry of Public Works is "highly averse to measures relating to construction, and totally opposed to any of its departments being called on to carry out any building inspection whatsoever" [9]. Without the participation and commitment of all involved, it is difficult to take any actions to reduce vulnerability.

Furthermore, this type of measure can be effective and relevant for new buildings, but comes too late for existing ones. Since 1980, when land-use regulations that took into account natural risks were not a priority, massive urban development has taken place, sometimes in flood-prone areas.

Finally, the main limit of these types of regulations arises from the lack of commitment to monitoring. But if controlling land occupation does not seem to be effective, there is still the possibility of implementing other measures for reducing vulnerability, both collective and individual.

\subsubsection{Mitigation influenced by experience more than by regulations}

The drafting and approval of regulations such as the PPR should result in the implementation of mitigation measures. The analysis of constructions permits in Cuxac-d'Aude, in the Aude department, showed that the population implemented individual measures for reducing vulnerability, in particular the building of a safe upper floor, which is recommended by authorities. But the longterm analysis showed that the PPR has little influence. The low plains of the Aude department were heavily affected by the catastrophic flooding of November 1999. The construction permit data shows a growth in mitigation measures immediately after the disaster, in the year 2000, and then an absence of these types of measures in the following years (Fig. 3).

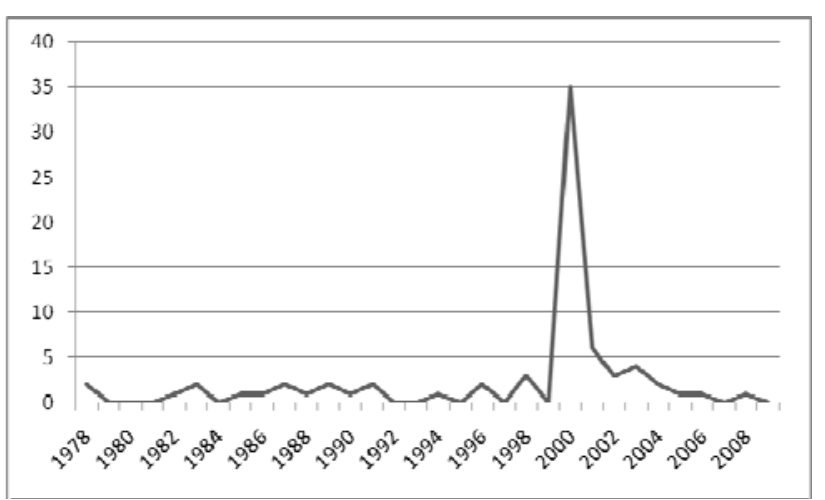

Figure 3. Measures of adaptation to risk (half story) in Cuxac-d'Aude

The experience of the event seems to have had a much greater influence than the PPR regulations implemented several years earlier.

Surveys were carried out in this same town (188 people surveyed). The results show homes that are rather vulnerable to flooding, with more than half being singlestory homes. Home construction does not depend on riskadaptation factors, but rather financial or lifestyle criteria [10], and this type of home increases potential damage and loss of life. Another survey in the town of Grabels showed that after the remarkable event, $10 \%$ of those surveyed were thinking about adding a safe upper floor. Residents showed a desire for protecting themselves individually. Here again, these decisions show that the event has more influence than regulations, since the question was not asked before the floods that hit the town in October of 2014. This desire, however, might not be followed by concrete actions, as several obstacles prevent residents from implementing adaptive measures. Cost is an obstacle, even if in some cases, institutions contribute financially to the implementation of mitigation measures. But cost is not the only problem, and the historicallypreferred technical approach still favors structural measures over preventive ones. After each event, identical reconstruction is dominant [12].

In general, local authorities and residents consider the Risk Prevention Plans (PPRs) to be a constraint [3, 6, 13, 14]. Regulations can affect local development and home sales, which makes it difficult for the PPR to gain acceptance and casts doubt on its effectiveness and relevance. In numerous cases, urban development continues, and the goals of the regulations are not achieved. In the cases studied, the measure does not appear to be effective or relevant in part because the measure is too late and difficult to apply, in particular because other priorities such as local development prevail.

Regulating land occupation is not an efficient measure, in particular with respect to existing measures. The implementation of complementary preventive measures such as crisis management preparation, as well as the transmission and preservation of knowledge and awareness of risks, appears to be necessary. 


\subsection{Can risk awareness reduce damage?}

We believe that informing the population and preparing for crisis management are complementary measures that should be put in place simultaneously with regulations. They bring together all the parties involved, in particular the population, allowing them to act to reduce the potential for damage and loss of life.

\subsubsection{Preventive information}

Preventive information has been growing since the 1980 s, but has not been integrated into regulations. After the many floods in the Mediterranean area at the end of the 1990s and beginning of 2000s, the government legislatively reinforced the obligation to inform and remind populations of risks. The main tools are public meetings, flood markers, and the legal obligation to inform buyers and renters if their home is in a floodprone area. Still, these measures have some shortcomings. Our various case studies show that this obligation is not always put into practice and that sometimes the information is not very specific and difficult for the public to understand. Numerous informative documents exist on the regional, department, and local scale. These documents describe the nature of the risk and give recommendations in case of crisis.

The evaluation of these measures through the analysis of the documents and through interviews and questionnaires shows differences by territory. The documents are customized by local authorities, and the contents thereof thus differ from place to place. Sometimes they are clear and comprehensible; other times, they give little information on the potential risk and on how to prepare for a crisis. Only a third of respondents in Grabels and half in Cuxac-d'Aude were aware of these documents, but they could not explain their contents. We believe that this type of document is important for facing a crisis, as awareness and knowledge make people better prepared. But this argument needs to be nuanced: even if the public is aware of this information, it does not guarantee that they will modify their behavior during a crisis, especially since stressful situations modify reflexes. Another criticism of this type of measure deals with accessibility. While these documents are available to the public and can be viewed, in particular over the Internet, it is the public that has to go find them. This means that people have to at least be aware that a potential risk exists in their community. To overcome this shortcoming, since 2006 this information must be provided to buyers and renters (IAL). Here again, the information is sometimes highly vague and requires prior knowledge to be understood. For example, it is difficult for the average person to read a map and figure out the precise location of their home in the at-risk area. Moreover, the maps included in the appendix of the IAL are sometimes hard to read, on a small scale, or only show an approximate location of the home. In addition, only the extent of the flood-prone area is shown, without giving the water levels to which the home may be exposed (Fig. 4).

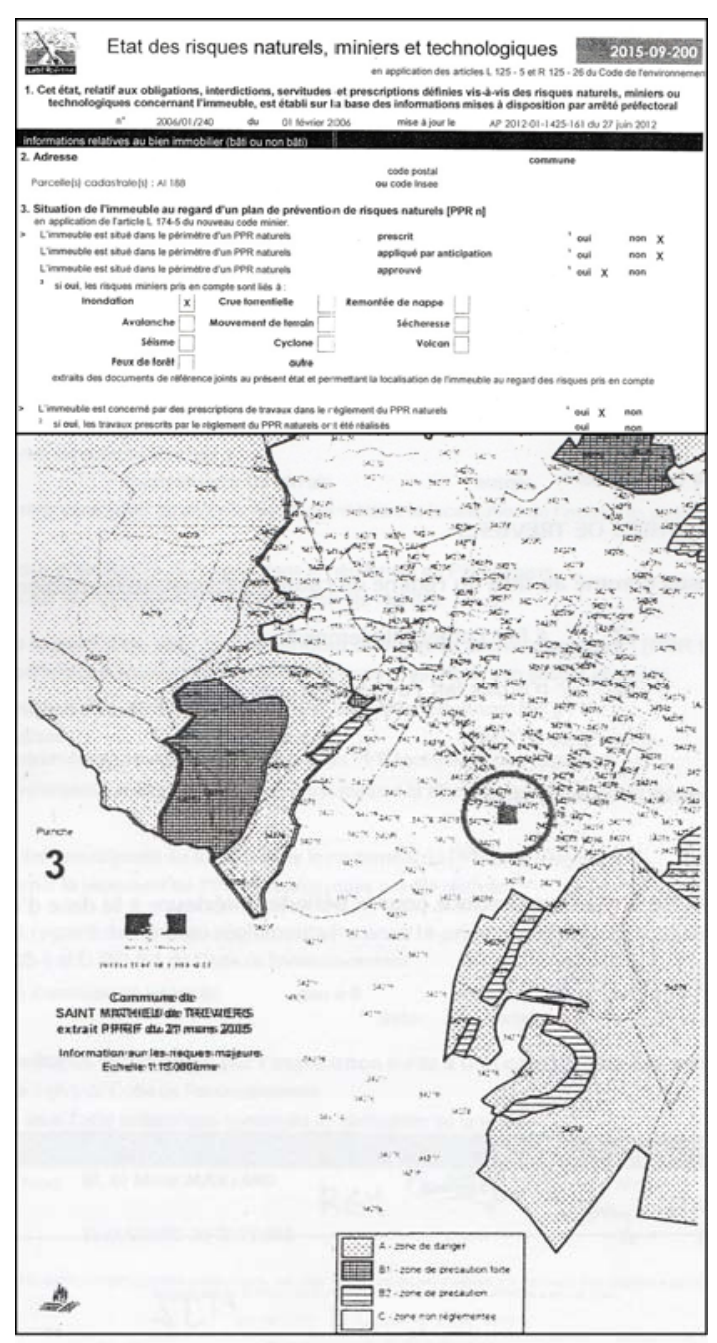

Figure 4. Extract from a Buyer-Renter Notice

The overall analysis of these types of measures is generally negative, and they do not really provide any solutions for reducing damage and loss of life.

\subsubsection{Preparation for crisis management: a preservation tool?}

Crisis management takes place on several levels and involves many players: institutions, emergency services, weather bureaus and civil society. Since 2000, numerous changes have taken place. Weather alerts have become an important crisis management tool, and public and private organizations work together to inform local authorities and the public. On the local scale, the Community Protection Plan (PCS) contains instructions to follow in case of a crisis. These types of measures have mixed results depending on the case.

During the flooding in Lamalou-les-Bains (Sept. 2014), a small tributary $5 \mathrm{~km}$ long caused heavy damage and 4 deaths. This type of stream is not subject to hydrological monitoring, so it is impossible to predict when water levels will rise or how fast this will occur. This is a significant shortcoming, even if it is difficult to provide equipment for such a small stream. In Grabels, 
the PCS was activated in October 2014 and the public was warned of the imminent flood by an automated phone alert. But interviews with local authorities show that the events could have ended differently. There was a power outage just a few minutes after the phone alert was triggered, and the damage could have been worse. Several days after the flood, interviews with residents revealed that the crisis was handled without the intervention of the authorities and by the fire department, which was alerted by the public itself. The public was not aware of their town's PCS and reacted on instinct, with multilevel houses taking in neighbors from single-story homes. In the Aude department in 1999, the PCS did not yet exist, but local authorities were warned by the weather bureaus. The only confusion and misunderstandings in alerting the public were caused by the local authorities' own difficulty in interpreting the information. These examples show the difficulty of transmitting information and applying certain measures locally. Despite the tools that have been developed, it is impossible to plan for everything during a crisis.

Just like for the evaluation of mitigation, these results show a major influence of the experience of an event in the implementation of measures. In areas that have not experienced an event in several years, preparation for crisis management is often lacking and is forgotten by both local authorities and the public. Unpredictable behavior also plays a key role during a crisis, as shown by the numerous deaths on the Côte d'Azur in September 2015 caused by ill-advised behavior. Measures and regulations cannot prevent certain types of risky behavior, but this behavior could be influenced by developing awareness and knowledge of the risk and of the preparations for crisis management.

It is difficult to evaluate the effectiveness and relevance of these types of measures, in particular because they are fairly recent and because they depend on the participation of all involved. Still, we can conclude that developing tools for preparing for crisis management can be effective. We believe that these tools, along with knowledge and awareness of the risk, can help reduce damage and loss of life.

\section{Preventive management lags behind structural measures that are dependent on events}

After many decades of risk management through structural measures, risk management is becoming more globalized with the integration of preventive measures that bring together all the parties involved.

The results of our research show that preventive measures are still in their infancy and that it will take time for them to be applied and accepted at the local level and overtake structural measures. The surveys carried out in Cuxac-d'Aude, Grabels and other areas (the Atlantic Coast after Xynthia) prove that the various players involved rely heavily on protection by dikes. This is the heritage of the technical approach of French authorities, who managed floods by building dikes, but structural measures have their limits and this mentality needs to change. These types of measures are also political statements: a dike is more visible than a PCS. Moreover, the public is used to structural measures, which give it a way to assign all responsibility for protection to authorities. Collective measures are broadly supported, even if our results show a desire to implement individual measures for reducing vulnerability, which, in our opinion, can be more effective.

Preventive measures are prescribed by laws, but they are also guided by the experience of an event. Although this experience does not always result in suitable behaviors, it gives a general idea and awareness of the risk. We can suppose that these populations are a little more prepared. In addition, an event leads to the implementation of individual and collective measures, even if the memory of the event fades (too) quickly. However, if no remarkable event occurs, those involved have no knowledge or awareness of the risk, and few measures are put in place to tackle the crisis. The potential damage is not assessed, the risk is not taken into account during decision-making, and there is little coordination of the various parties involved. In our studies, the absence of an event means a lack of commitment to prevention and preparation for crisis management.

Our evaluation of these locations reveals the difficulty of applying preventive measures and the work that remains to be done. In conclusion, risk management does not appear to be a priority for local authorities, even if the expectations of less damage and loss of life are high. Global, concerted management does not always seem to be suitable in the local context, and the lack of prevention goals makes this management all too superficial.

\section{References}

1. Deleau M and Nioche J P (1986). Evaluer les politiques publiques : méthodes, déontologie, organisation. Rapport pour le Commissariat Général du Plan, la Documentation Française, Paris, 180 p.

2. Pottier N., 1998, L'utilisation des outils juridiques de prévention des risques d'inondation : évaluation des effets sur l'homme et l'occupation des sols dans les plaines alluviales (application à la Saône et à la Marne, Thèse de Doctorat de l'Ecole Nationale des Ponts et Chaussées, Spécialité Sciences et Techniques de l'Environnement, $582 \mathrm{p}$.

3. Defossez S. (2009). Evaluation des mesures de gestion du risque inondation. Application au cas des basses plaines de l'Aude, thèse de doctorat, université Montpellier 3, 462 p. + annexes

4. Heaumé C, (2015). Evolution des perceptions du risque inondation dans les basses plaines de l'Aude. Rapport de stage effectué au sein de l'UMR GRED, Montpellier, $85 \mathrm{p}$.

5. Vinet, F., Boissier L., Defossez S, 2011, « La mortalité comme expression de la vulnérabilité humaine face aux catastrophes naturelles : deux 
inondations récentes en France (Xynthia, var, 2010) », VertigO- la revue électronique en sciences de l'environnement, Volume 11 Numéro 2, [En ligne] URL : http:// vertigo.revues.org/11074

6. Rey T., Defossez S., Vinet F., Boissier L. (accepted). Cinématique et impacts d'un évènement hydrométéorologique: les inondations du 6-7 octobre 2014, Grabels (France méditerranéenne), Vertigo, $20 \mathrm{p}$.

7. Leone F. Vinet F., Denain J.C., Bachri S., 2007, Développement d'une méthodologie d'analyse spatiale des destructions consécutives au tsunami du 26 décembre 2004 (Banda Aceh, Indonésie). Premiers résultats pour l'élaboration de futurs scénarios de risque, Géocarrefour, Vol. 82, n¹-2, (numéro spécial risques et territoires), pp. 77-90

8. Lagahe E., Vinet F. (2014) Evaluation de la vulnérabilité des logements face à la submersion marine sur l'île d'Oléron. Projet dans le cadre du projet Risks porté par l'UMR Liens, Université la Rochelle et du PAPI « île d'Oléron, 102 p.

9. Barthélémy F., Lazergues R., Linet M., Pin X., Quevremont P. (2006). Organisation de la prévention des risques naturels dans les services déconcentrés. Rapport de l'IGE 25/054, 20 p. + annexes.

10. Madoré (2004). Les ensembles résidentiels fermés en France, Les Annales de la recherche urbaine, METATTM, $\mathrm{n}^{\circ} 95$, Apprivoiser les catastrophes, p. 99-106.

11. Druon E. (2015). Gestion de crise et vulnérabilité face aux crues torrentielles, étude des facteurs limitant la catastrophe: retour d'expérience sur l'inondation $d u$ 6-7 octobre 2014 à Grabels (France), mémoire de master 1 GCRN, 98

12. Veyret Y and Laganier R. (dir). (2013). Atlas des risques en France. Prévenir les catastrophes naturelles et technologiques. Paris, éditions Autrement, collection Atlas/Monde, 96 p.

13. Douvinet J., Defossez S., Anselle A., Denolle A-S. (2011). Les maires face aux plans de prévention du risque inondation (PPRI). L'espace géographique, 1/2001, tome 40, p. 31-49.

14. Caumont V. and Fasquel F. (2012). Risque de submersion marine et marches fonciers et immobiliers sur le littoral du Nord-Pas-de-Calais. Phase 1: Approche qualitative des marchés et exemples d'adaptations, CETE Nord Picardie, 33 p. 